\title{
Media Pembelajaran Berbasis Model Bruner, Budaya Lokal, dan Scaffolding untuk Meningkatkan Pemahaman Konsep Relasi dan Fungsi
}

\author{
Ni Wayan Poppy Handayani ${ }^{*}$, I Made Ardana ${ }^{2}$, I Gusti Putu Sudiarta ${ }^{3}$ \\ 1,2,3Pendidikan Matematika, Universitas Pendidikan Ganesha, Singaraja, Indonesia; \\ 1poppyhandayani0378@gmail.com, ${ }^{2}$ ardanaimade@yahoo.com, ${ }^{3}$ gussudiarta@undiksha.ac.id
}

Info Artikel: Dikirim: 16 Februari 2020; Direvisi: 5 April 2020; Diterima: 8 September 2020

Cara sitasi: Handayani, N.W.P, Ardana, I.M., \& Sudiarta, I.G.P. (2020). Media Pembelajaran

Berbasis Model Bruner, Budaya Lokal, dan Scaffolding untuk Meningkatkan Pemahaman

Konsep Relasi dan Fungsi. JNPM (Jurnal Nasional Pendidikan Matematika), 4(2), 221-236.

\begin{abstract}
Abstrak. Penelitian ini berawal dari rendahnya pemahaman konsep siswa terhadap materi fungsi. Tujuan penelitian ini untuk mendeskripsikan efektivitas media pembelajaran berbasis Model Bruner, Budaya Lokal, dan Scaffolding (B2LS) untuk meningkatkan pemahaman konsep relasi dan fungsi. Penelitian mengacu pada metode pengembangan Plomp yang terdiri atas 3 fase: Preliminary Research, Prototyping, dan Assesment. Rangkaian fase melibatkan dua ahli pendidikan matematika, satu guru dan 105 siswa kelas VIII SMPN Denpasar sebagai subjek penelitian. Media yang dikembangkan berupa media pembelajaran berbasis TIK dengan aplikasi Autoplay Media Studio. Data yang dikumpulkan melalui lembar validasi, lembar kepraktisan, angket respons dan tes pemahaman yang selanjutnya dianalisis secara kualitatif dan kuantitatif. Hasil penelitian menunjukkan bahwa media pembelajaran efektif dalam meningkatkan pemahaman konsep relasi dan fungsi. Hal ini didasarkan pada karakteristik media yaitu: siswa mengkonstruksi pemahamannya melalui teori Bruner, konsepsi jengah untuk mendukung peningkatan pemahaman konsep, dan scaffolding untuk membantu memahami konsep lebih jelas. Sehingga melalui media pembelajaran ini, siswa akan mudah memahami konsep relasi fungsi dan termotivasi dalam menyelesaikan masalah.
\end{abstract}

Kata Kunci: Media Pembelajaran, Bruner, Scaffolding, Jengah.

Abstract. This research begins with the lack of students' conceptual understanding of relation and function. This research aimed to describe learning media's effectiveness based on the Bruner, Local Culture, and Scaffolding Model (B2LS) to improve the student conceptual understanding of relations and functions. The development of this research used Plomp's procedures that consist of 3 phases: Preliminary Research, Prototyping, and Assessment. It was done by involving two mathematics education experts, one teacher and 105 students of grade VIII of State Junior High School in Denpasar as research subjects. Learning tools developed were ICT-based learning media with Autoplay Media Studio Applications. Data were collected through validation and practicality sheets, response questionnaires, and 
comprehension tests. The data were analyzed qualitatively and quantitatively. The results showed that learning media could improve students' conceptual understanding of relation and function. It is caused by the media's characteristics such as students construct their understanding through Bruner's theory; learning media contains a conception of embarrassment, and scaffolding to help students understand concepts more clearly and easily. So that through B2LS based learning media, students will quickly understand the concept of relation and function and be motivated to solve problems.

Keywords: Effectiveness, Media, Bruner, Scaffolding, Jengah.

\section{Pendahuluan}

Fungsi merupakan konsep penting dalam perkembangan cabang ilmu matematika seperti aljabar, kalkulus, analisis dan geometri, ekonometri, dan statistik (Akçakın, 2018; Fonger, Ellis \& Dogan, 2016; McCulloch, Lovett \& Edgington, 2017). Bahkan perkembangan bidang teknik, teknologi, dan informasi yang merupakan buah dari perkembangan ilmu pengetahuan juga banyak mengaplikasikan konsep fungsi di dalamnya (McCulloch, Lovett \& Edgington, 2017). Sehingga, konsep ini memiliki tingkat urgensi tinggi untuk dikuasai oleh orang yang akan dan sedang belajar matematika.

Secara harfiah, fungsi yang memiliki hubungan erat dengan kehidupan didefinisikan sebagai sebuah aturan yang menghubungkan setiap elemen domain dengan tepat satu elemen di kodomain (Denbel, 2015). Banyak hubungan antar fenomena-fenomena dalam kehidupan sehari-hari dapat dinyatakan sebagai fungsi, misalnya hubungan antara kecepatan mobil dengan jarak yang ditempuh, begitupula jarak tempuh dengan bahan bakar yang dihabiskan merupakan salah satu contoh aplikasi konsep fungsi.

Namun, kenyataan menunjukkan bahwa fungsi bukanlah materi yang mudah untuk dipahami siswa (Akçakın, 2018). Siswa sering mengalami kebingungan dalam membedakan antara relasi dan fungsi. Selain itu, mereka kesulitan menyajikan fungsi ke dalam bentuk yang benar sehingga mereka tidak dapat memecahkan masalah dengan tepat. Kegagalan dan kesulitan inilah yang menyebabkan siswa sering kali melakukan kesalahan (McCulloch, Lovett \& Edgington, 2017). Kesulitan dan kesalahan ini muncul sebagai buah akibat dari lemahnya kemampuan siswa dalam memahami konsep relasi dan fungsi.

Guna meminimalisir kesalahan ataupun kesulitan siswa dalam memahami konsep relasi dan fungsi, maka inovasi dalam proses pembelajaran seperti pemilihan model pembelajaran sangatlah diperlukan (Serdyukov, 2017). Purwadi (2019) menyatakan bahwa ketepatan pemilihan model 
pembelajaran guna memberikan pengaruh yang signifikan tehadap hasil belajar merupakan sebuah inovasi yang harus guru lakukan. Pembelajaran dengan model Bruner, Budaya Lokal, dan Scaffolding (B2LS) dapat dijadikan sebuah alternatif untuk mempermudah siswa dalam memahami konsep relasi dan fungsi.

Keistimewaan dari model B2LS dalam pembelajaran materi fungsi terletak pada sintaks pembelajarannya. Hal ini dapat dilakukan dengan mengenalkan konsep fungsi melalui konteks kehidupan real siswa. Siswa diberikan konteks sedemikian sehingga mereka dapat menghubungkan setiap masalah yang diberikan guru sesuai arahan dan petunjuk yang diberikan. Setelah siswa mampu memahami konsep awal dari relasi dan fungsi barulah pembelajaran diarahkan pada penyajian fungsi berupa penggambaran dalam bentuk tabel maupun diagram. Fase ini sama dengan tahapan ikonik dan simbolik secara berturut-turut pada teori Bruner. Keistimewaan lain pada B2LS ini juga sangat tergambar pada fase scaffolding dan budaya lokalnya. Setelah siswa mempelajari cara penyajian fungsi, mereka akan diarahkan untuk memahami fungsi secara aljabar. Disinilah bagian scaffolding berperan. Dengan kelihaian guru dalam mengatur pembelajaran sehingga siswa mudah memahami materi aljabar fungsi. Selanjutnya budaya lokal tergambarkan dalam kalimat-kalimat motivasi yang bisa guru sematkan dalam proses diskusi maupun pemecahan sebuah masalah agar siswa tidak mudah menyerah.

Selengkapnya, dipaparkan oleh Ardana (2016) bahwa pembelajaran B2LS merupakan pembelajaran yang mendorong siswa untuk membangun pengetahuan baru, mencari pijakan awal sebagai landasan berpikir dan mencoba berbagai kemungkinan penyelesaian masalah melalui representasi Bruner yakni: enactive, iconic, dan symbolic. Ketiga representasi ini saling berkaitan satu sama lain dan digunakan secara interaktif (Matsumoto, 2017). Enaktif berarti siswa dalam belajarnya menggunakan atau memanipulasi objek secara langsung. Iconic berarti pengetahuan disajikan dalam sekumpulan gambar-gambar yang mewakili suatu konsep. Simbolik berarti menggunakan simbol-simbol matematika secara langsung (Sani, 2017; Takaya, 2008; Winer \& Schmid, 2017).

Selanjutnya guru memotivasi siswa dengan konsepsi jengah agar mereka mampu menunjukkan pemahamannya terkait konsep yang dipelajari. Ditegaskan oleh Ardana (2015) bahwa taksu dan jengah merupakan kekuatan utama kebudayaan Bali. Jengah menjadi basis kreativitas masyarakat Bali dalam kehidupan dan kebudayaan dengan menjadikan keunggulan 
kompetitif sebagai penyemangat dalam berkreasi. Jadi konsepsi jengah dalam kontek budaya yang dimanfaatkan pada model B2LS memiliki konotasi semangat yang memotivasi. Memaksimalkan konsepsi jengah bertujuan untuk menghambat timbulnya sikap pasif dan mudah menyerah.

Saat siswa mencoba memahami konsep matematika yang dipelajari, akan terjadi konflik kognitif pada siswa berkaitan dengan kesimpulan yang mereka buat dengan prakonsepsi yang dimilikinya dan menggunakan faktafakta baru untuk memperbaiki kesalahpahaman mereka sebelumnya. Jika prakonsepsi sesuai, guru dapat mengarahkan siswa untuk mengatur informasi yang mendukung ide-ide mereka menuju kesimpulan akhir. Namun, apabila terjadi kebuntuan saat melakukan investigasi, maka guru dapat memfasilitasi dengan bantuan yang bersifat scaffolding sehingga mereka mampu mencapai pemahaman mendalam sesuai dengan potensinya.

Scaffolding ini merupakan sebuah bantuan yang diberikan oleh orang yang lebih kompeten baik teman sebaya maupun guru (Ormond, 2016). Scaffolding erat kaitannya dengan Zone of Proximal Development (ZPD). ZPD merupakan jarak antara tingkat perkembangan aktual dengan tingkat perkembangan potensial yang lebih tinggi. Siswa mampu mencapai daerah maksimal apabila dibantu secukupnya. Apabila tidak dibantu siswa tetap berada pada daerah aktualnya tanpa bisa berkembang ke tingkat perkembangan potensialnya. Namun, perlu diperhatikan cara menyusun scaffolding yang efektif dan efisien sehingga dapat mengembangkan kemampuan aktual siswa kearah potensialnya (Gonulal \& Loewen, 2018; Ormond, 2016).

Disamping itu, konsep relasi dan fungsi merupakan materi yang cukup esensial dalam kurikulum matematika sekolah sehingga dalam mempelajarinya perlu dibantu oleh media pembelajaran yang memadai. Jika media dirancang dengan baik maka hal tersebut dapat membantu siswa dalam memahami materi pelajaran (Muhson, 2010).

Beberapa hasil penelitian pun telah mendeskripsikan bahwa media autoplay efektif diterapkan dalam pembelajaran matematika. Pertama, pengembangan dari Wandani \& Syaiful (2017) yang menunjukkan bahwa media pembelajaran yang berbasis autoplay dapat digunakan untuk mengajarkan materi kedudukan relative dua buah lingkaran. Kedua, penelitian oleh Novyarti, Marzal \& Rohati, (2014) yang menyimpulkan bahwa pengembangan media interaktive berbasis autoplay dapat meningkatkan kemampuan siswa kelas VII dalam memahami materi garis dan sudut. Selain 
terkait media pembelajaran, terdapat juga hasil penelitian menunjukkan bahwa model pembelajaran B2LS efektif diterapkan pada pembelajaran matematika. Hal itu terlihat dari hasil penelitian Ardana (2014) yang mengatakan bahwa aktivitas belajar siswa sangat tinggi, prestasi belajar siswa baik, dan tanggapan siswa positif terhadap pembelajaran dengan model B2LS.

Senada dengan hasil penelitian-penelitian di atas, peneliti menduga bahwa model B2LS akan lebih optimal dalam peranannya untuk meningkatkan pemahaman konsep siswa jika dibantu oleh media autoplay. Media ini akan membantu dalam menyajikan pembelajaran dengan 3 tahapan teori Bruner yang ada pada sintaks model B2LS yang lebih interaktif sehingga siswa akan memiliki ketertarikan yang lebih baik jika dibandingkan dengan tanpa menggunakan media autoplay. Melalui media ini juga dapat mewakili apa yang kurang mampu guru ucapkan melalui kata-kata atau kalimat tertentu seperti konsepsi jengah yang ada pada B2LS. Untuk menumbuhkan konsepsi jengah harus ada tantangan yang dilalui siswa salah satunya tantangan yang telah dirancang pada media autoplay tersebut. Scaffolding yang rumit di sampaikan dengan kata-kata, dapat lebih mudah dipahami apabila siswa melihat dan mengalami langsung melalui media tersebut.

Berdasarkan uraian di atas, tujuan dari penelitian ini adalah untuk mendeskripsikan efektivitas media pembelajaran berbasis Model Bruner, Budaya Lokal, dan Scaffolding (B2LS) untuk meningkatkan pemahaman konsep relasi fungsi.

\section{Metode}

Penelitian ini dilakukan dengan pendekatan pengembangan. Sehingga penelitian ini menghasilkan produk berupa media pembelajaran berbasis model "B2LS" yang selanjutnya diuji keefektifannya. Prosedur pengembangan yang digunakan adalah prosedur menurut Plomp yang terdiri dari 3 fase yaitu: 1) Preliminary Research (Tahap Penelitian Awal), 2) Prototyping (Tahap Prototipe), dan 3) Assesment (Tahap Penilaian). Berikut rincian kegiatan pada masing-masing tahapan.

Tahap Penelitian Awal peneliti mencari informasi ke salah satu guru matematika kelas VIII mengenai kurikulum yang digunakan di sekolah tersebut, mengkaji media-media pembelajaran yang digunakan guru maupun siswa, serta melakukan wawancara bersama siswa dan guru matematika mengenai pembelajaran matematika yang tengah berjalan. Setelah itu dilakukan pengembangan kerangka konseptual dan teori untuk 
merancang sebuah media pembelajaran dan instrumen yang diperlukan, seperti lembar validasi, lembar keterlaksanaan media pembelajaran, angket respon guru dan siswa, dan tes pemahaman konsep.

Tahap Prototipe ini media pembelajaran yang telah dihasilkan dilihat kualitasnya dengan cara diuji validitas, kepraktisan, dan keefektifannya melalui uji terbatas dan uji lapangan I serta melakukan revisi terhadap media pembelajaran tersebut.

Tahap Penilaian dilaksanakan uji coba lapangan II dengan melibatkan siswa pada kelas yang berbeda dan pada tahap akhir siswa diberikan berupa tes pemahaman konsep matematika untuk mengetahui keefektifan media pembelajaran dan angket respon siswa untuk melihat kepraktisan media pembelajaran (Sugiyono, 2017)

Penelitian ini dilaksanakan di SMP Negeri di Denpasar pada semester ganjil tahun ajaran 2019/2020. Subjek penelitian yaitu dua ahli yang merupakan dosen S-2 pendidikan matematika Undiksha, 35 siswa kelas VIII SMP Negeri di Denpasar sebagai uji coba terbatas, 35 siswa VIII sebagai uji coba lapangan I, 35 siswa VIII sebagai uji coba lapangan II, dan satu guru matematika SMP Negeri di Denpasar.

Instrumen dalam penelitian ini menggunakan angket, tes, dan catatan harian yang telah dirancang pada tahap penelitian awal. Untuk mengetahui kualitas media pembelajaran peneliti mengumpulkan data penelitian dengan metode 1) kevalidan media pembelajaran menggunakan angket yang dinilai oleh dua orang dosen dan satu orang guru matematika dengan kriteria valid yang baik yaitu $\bar{x}>23,33$; 2) kepraktisan media pembelajaran menggunakan angket respon siswa dengan kriteria praktis yaitu $37,40<\bar{x} \leq 46,20$, dan respon guru terhadap media pembelajaran yang telah digunakan dengan kriteria praktis yaitu $40,80<\bar{x} \leq 50,40$; 3) efektivitas media pembelajaran menggunakan tes pemahaman konsep yang dilaksanakan di akhir pertemuan dengan nilai tes diatas KKM yaitu 7,0 serta catatan harian yang telah dibuat selama penelitian berlangsung.

Analisis data dalam penelitian ini menggunakan analisis data kualitatif dan kuantitatif. Teknik analisis data deskriptif kualitatif dilakukan dengan mengelompokan informasi-informasi dari data kualitatif berupa masukan, tanggapan, kritik, dan saran perbaikan yang terdapat pada angket. Hasil data ini kemudian digunakan untuk merevisi produk yang dikembangkan. Teknik analisis data deskritif kuantitatif digunakan untuk mengetahui 
validitas, kepraktisan, dan efektivitas media pembelajaran yang dikembangkan.

\section{Hasil dan Pembahasan}

Hasil uji validitas media pembelajaran disajikan pada Tabel 1 dan Tabel 2.

Tabel 1. Hasil Penilaian Media Pembelajaran dari Ahli Media Pembelajaran

\begin{tabular}{cc}
\hline Validator & Skor \\
\hline Ahli 1 & 28 \\
Ahli 2 & 29 \\
Ahli 3 & 27 \\
Rata-rata Skor Total & 27,9 \\
Kriteria & Baik (Valid) \\
\hline
\end{tabular}

Tabel 1 menunjukan bahwa rata-rata skor validitas media pembelajaran yang dikembangkan sebesar 27,9 yang berada pada interval $\bar{x}>23,33$ dengan kriteria baik atau valid. Dalam proses penilaian dan validasi, para ahli memberikan beberapa komentar dan saran untuk perbaikan media pembelajaran yang dikembangkan. Adapun saran dari ahli media pembelajaran, antara lain: 1) petunjuk instalasi media ditunjukkan bukan hanya untuk antivirus smadav saja; 2) berikan petunjuk yang jelas apa yang harus dilakukan siswa di setiap halaman eksplorasi; 3) tambahkan navigasi untuk dapat balik ke halaman sebelumnya atau halaman utama; 4) mengganti beberapa gambar agar lebih menarik; 5) memperbaiki beberapa kalimat yang ada pada media agar mudah dipahami.

Tabel 2. Hasil Penilaian Media Pembelajaran dari Ahli Materi

\begin{tabular}{cc}
\hline Validator & Skor \\
\hline Ahli 1 & 28 \\
Ahli 2 & 27 \\
Ahli 3 & 29 \\
Rata-rata Skor Total & 28,3 \\
Kriteria & Baik (Valid) \\
\hline
\end{tabular}

Tabel 2 menunjukan bahwa rata-rata skor validitas media pembelajaran yang dikembangkan sebesar 28,3 yang berada pada interval $\bar{x}>23,33$ dengan kriteria baik atau valid. Dalam proses penilaian dan validasi, para ahli materi memberikan komentar dan saran untuk perbaikan media yang dikembangkan. Adapun saran perbaikan yang diberikan oleh ahli materi adalah kata-kata pada LKS di media harus jelas, agar mudah dipahami siswa untuk mengeksplorasi, perbanyak soal-soal latihan, dan cantumkan umpan balik ke siswa untuk memotivasi siswa. 
Berdasarkan hasil analisis angket respon siswa diperoleh bahwa rata-rata skor kepraktisan dari angket respons siswa adalah 45,94. Sehingga berdasarkan kriteria kepraktisan angket respon siswa, skor yang berada pada interval 37,40 $<\bar{x} \leq 46,20$ dapat dikatakan bahwa media pembelajaran yang dikembangkan berkriteria baik dalam aspek kepraktisan. Dari hasil analisis angket respon guru diperoleh bahwa skor total kepraktisan dari angket respons guru adalah 50 . Skor tersebut berada pada interval $40,80<\bar{x}$ $\leq 50,40$ dengan kata lain bahwa media pembelajaran yang dikembangkan berkriteria baik dalam aspek kepraktisan.

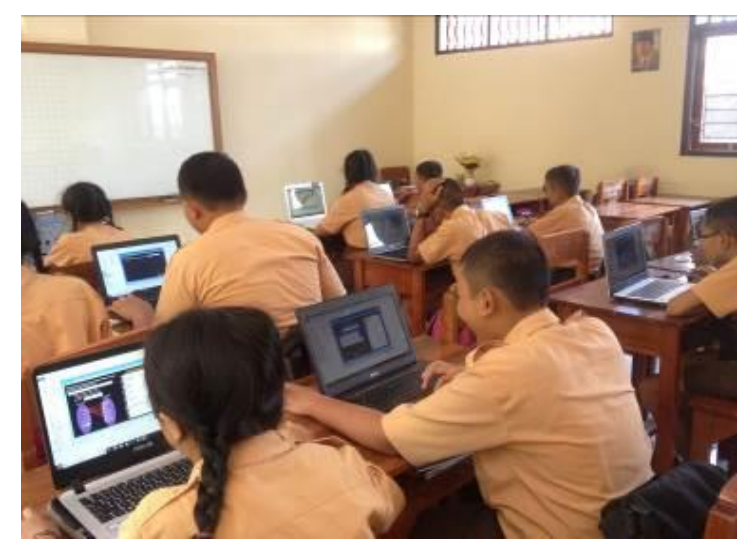

Gambar 1. Uji coba media pembelajaran

Gambar 1 merupakan salah satu foto uji coba lapangan yang dilakukan di kelas VIII. Setelah melakukan uji coba, selanjutnya diadakan tes pemahaman konsep matematika terhadap siswa tersebut. Adapun rangkuman analisis kuantitatif hasil tes pemahaman konsep matematika siswa pada uji coba lapangan 1 dan uji coba lapangan 2 dapat dilihat pada Tabel 3 berikut.

Tabel 3. Rangkuman Analisis Kuantitatif Hasil Tes Pemahaman Konsep Matematika

\begin{tabular}{ccccccc}
\hline Uji Coba & Nilai & Nilai & Rata-rata & Median & Modus & Kriteria \\
Lapangan & Max & Min & Skor & & & \\
\hline I (kelas VIII A) & 98 & 51,07 & 78,09 & 78,75 & 74,28 & Tuntas \\
II (kelas VIII B) & 99 & 51,5 & 79,88 & 85,5 & 60,5 & Tuntas \\
\hline
\end{tabular}

Tabel 3 menunjukan bahwa rata-rata skor tes pemahaman konsep matematika untuk siswa kelas VIII A dan VIII B telah memenuhi kriteria dalam pengembangan media. Berdasarkan tabel diatas diketahui bahwa rata-rata nilai siswa adalah sebesar 78,09 pada uji coba lapangan I dan 79,88 pada uji coba lapangan II. Angka tersebut menunjukkan bahwa hasil tes pemahaman konsep tergolong dalam kategori "Tuntas" karena nilai ini terletak pada interval $70 \leq \bar{x} \leq 100$. 
Selain dilakukan analisis kuantitatif, peneliti juga melakukan analisis kualitatif untuk melihat keefektifan media pembelajaran yang dikembangkan. Analisis kualitatif ini diambil dari catatan harian yang telah dilakukan selama proses penelitian. Adapun temuan-temuan yang diperoleh yaitu siswa sudah terlibat aktif dalam proses pembelajaran, sudah mampu menemukan konsep relasi dan fungsi dengan bantuan media pembelajaran yang sudah disiapkan, dan siswa sudah mulai terbiasa belajar melalui perbuatan atau tindakan nyata terlebih dahulu sebelum masuk ke tahap yang lebih abstrak. Hal ini akan membuka pikiran siswa bahwa matematika itu berguna dan ada dalam kehidupan nyata. Terlibat aktifnya siswa selama proses pembelajaran dipengaruhi oleh adanya penggunaan media pembelajaran yang membantu siswa menemukan kembali konsep relasi dan fungsi yang diharapkan. Ini sejalan dengan beberapa penelitian Razak \& Rumainur (2018) dan Novyarti (2014) yang menyatakan bahwa Autoplay Media Studio sangat baik digunakan untuk merancang media pembelajaran yang sesuai dengan kebutuhan siswa dalam memahami konsep. Selain itu, dengan penerapan model B2LS siswa lebih banyak memiliki waktu untuk mengkonstruksi pengetahuannya sendiri karena proses pembelajarannya berpusat kepada siswa serta melalui 3 tahapan belajar Bruner.

Hasil penelitian di atas menunjukkan bahwa pengembangan media belajar berbasis model B2LS efektif digunakan dalam meningkatakan pemahaman konsep relasi dan fungsi. Hal ini dikarenakan model B2LS merupakan model pembelajaran yang berorientasi pada teori Bruner, Budaya Lokal (konsepsi jengah) dan Scaffolding (Ardana, 2014; Ardana, 2015; Ardana, 2016). Keefektifan dari media ini tidak terlepas dari karakteristik media pembelajaran yang berhasil dikembangkan. Karakteristik pertama yaitu kegiatan pembelajaran pada media sesuai dengan tahapan teori Bruner. Salah satu teori pendukung dari model B2LS adalah teori Bruner yaitu (1) enactive/belajar melalui berbuat atau bertindak (Sani, 2017), (2) iconic/belajar melalui arti dari gambar, skema, grafik, tabel, diagram dan lain-lain (Winer \& Schmid, 2017), (3) symbolic/belajar melalui kata-kata atau angka (Ardana, Ariawan \& Divayana, 2018).

Kegiatan sebelum menggunakan media pembelajaran ini yaitu guru harus memberikan sebuah apersepsi yang nyata (tahap enaktif) bagi siswa agar selaras dengan yang terdapat pada media. Pada kegiatan ini guru mengajak siswa untuk belajar melalui berbuat atau melakukan suatu tindakan yang nantinya berkaitan dengan media pembelajaran. Melalui tahap enaktif ini dapat meningkatkan ketertarikan siswa untuk belajar karena siswa mengalami langsung hal yang dipelajari. Dalam penelitian yang dilakukan 
oleh Lovita (2017) juga dikatakan bahwa belajar melalui berbuat/tindakan langsung memiliki manfaat yang besar dalam berlangsungnya proses pembelajaran. Selain dapat memberikan gambaran yang nyata tentang suatu objek, tindakan nyata juga memungkinkan siswa untuk belajar secara mandiri dan ikut terlibat secara aktif dalam proses pembelajaran sehingga meningkatkan gairah dan motivasi belajar siswa dan pada akhirnya dapat meningkatkan hasil belajar (Ardana, 2016).
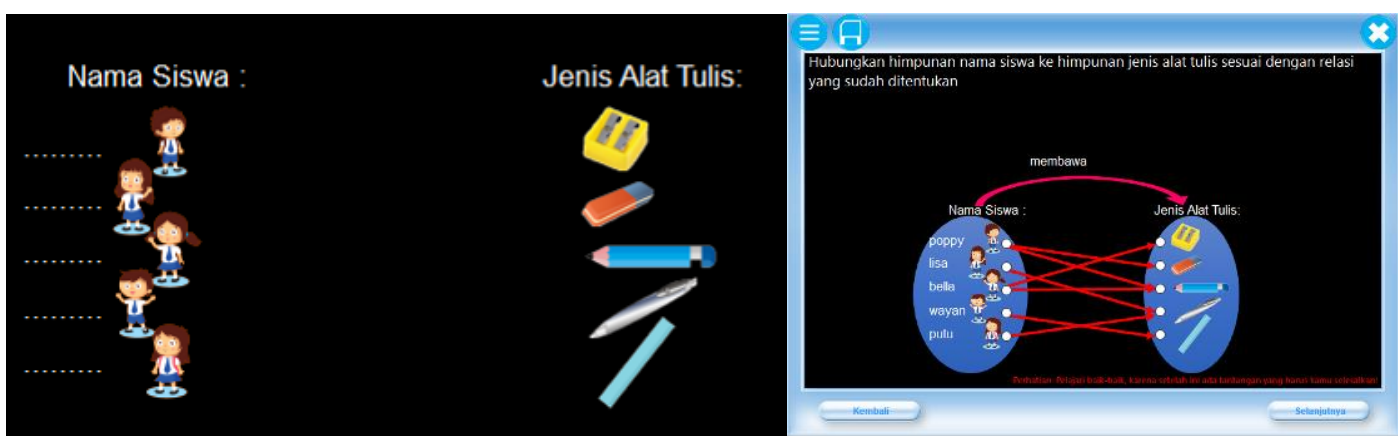

Gambar 2. Eksplorasi tahap ikonik

Pada media pembelajaran terdapat tahap eksplorasi seperti pada gambar 2 berupa gambaran nyata terkait materi yang guru berikan pada bagian apersepsi di awal pembelajaran (tahap ikonik). Siswa melakukan hal yang sama seperti pada tahap enaktif, namun dilakukannya pada media pembelajaran melalui gambar. Pada tahap ikonik ini siswa dapat mengkonstruksi konsep dasar yang perlu dikuasai sebelum masuk ke tahap simbolik. Manfaat secara umum belajar melalui gambar menurut penelitian yang dilakukan oleh Rosmayanti (2018) ialah dapat mempermudah dan memperjelas pemahaman sesuatu yang penting atau yang ingin disampaikan pada siswa.

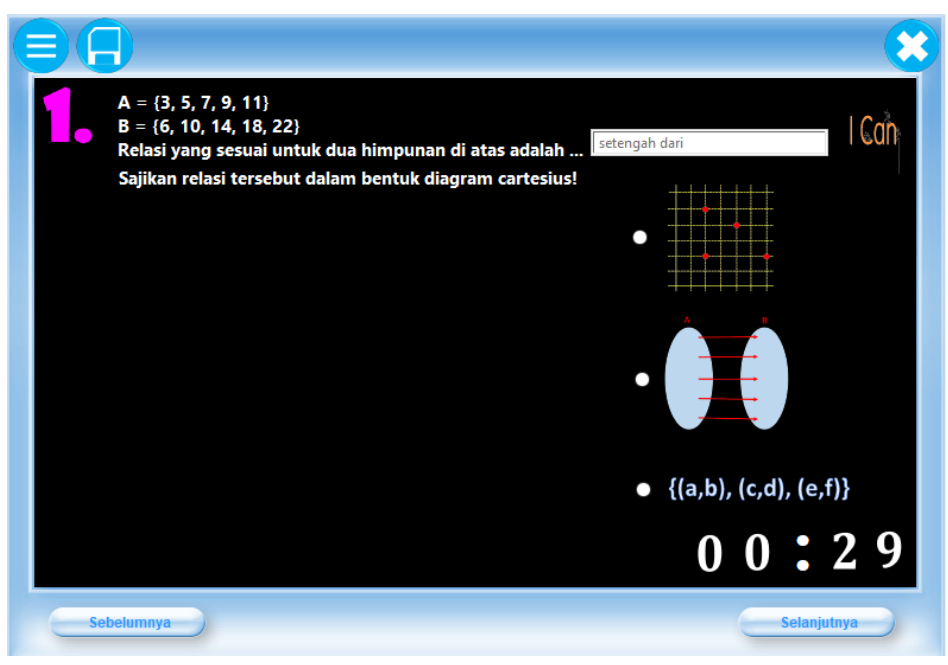

Gambar 3. Eksplorasi tahap simbolik 
Tahap simbolik berkaitan dengan simbol-simbol yang sering digunakan pada matematika khususnya materi relasi dan fungsi (Matsumoto, 2017) seperti pada gambar 3. Menurut Lestari (2013) penggunaan tiga representatif teori Bruner ini dapat membantu siswa mengingat, memahami, mengolah serta dapat mengemukakan seluruh pengetahuannya mengenai suatu konsep untuk selanjutnya digunakan dalam penyelesaian masalah.

Karakteristik yang kedua yaitu media pembelajaran memuat konsepsi jengah untuk mendukung peningkatan pemahaman konsep matematika siswa. Media pembelajaran memuat konsepsi jengah untuk memotivasi siswa dalam belajar. Ardana, Ariawan \& Divayana, (2018) mengatakan bahwa konsepsi jengah dalam konteks budaya memiliki konotasi semangat. Konsep inilah yang perlu ditumbuhkembangkan pada diri siswa sehingga segala sesuatu yang dipelajari relatif mudah untuk dipahami.

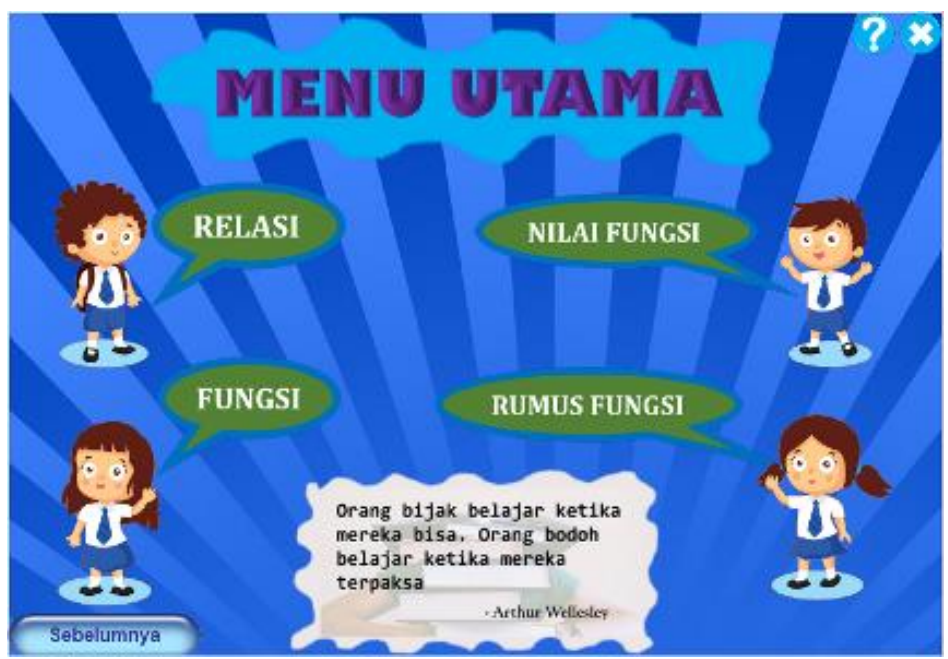

Gambar 4. Sisipan kalimat motivasi pada media

Gambar 4 menunjukan aplikasi pembelajaran membangkitkan konsepsi jengah pada siswa melalui kalimat-kalimat sugesti yang dimunculkan pada aplikasi pembelajaran, "Rasa ingin tahu akan mengalahkan rasa takut, bahkan melebihi keberanian”, "Jangan pernah berhenti belajar, karena hidup tak pernah berhenti mengajarkan", "Dengan bekal ilmu, seseorang bisa bertahan hidup". Konsepsi jengah ini akan mampu memotivasi siswa dalam belajar sebab konsepsi jengah dapat merupakan motor penggerak dari setiap kegiatan yang dikerjakan, dapat memberikan arah kegiatan, yakni ke arah tujuan yang hendak dicapai, dan mampu menentukan perbuatan-perbuatan apa yang harus dilakukan guna mencapai tujuan. 


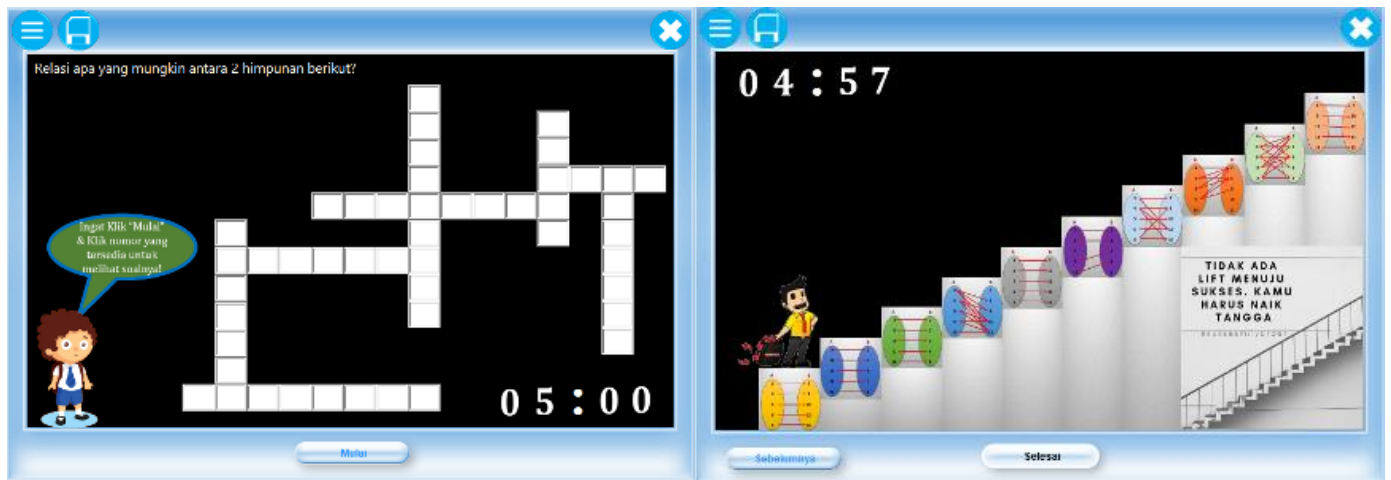

Gambar 5. Tantangan yang harus diselesaikan siswa untuk menumbuhkan rasa jengah

Selain melalui kata-kata motivasi, melalui tantangan-tantangan yang ada seperti gambar 5 tersebut juga mampu membangkitkan rasa jengah siswa. Hal itu terlihat dari siswa antusias untuk bersaing dengan siswa lain agar dapat menyelesaikan lebih dulu tantangan yang ada pada media. Tujuan memaksimalkan konsepsi jengah ini untuk menghindari munculnya konsepsi nasib pada siswa (Ardana, 2016). Konsepsi nasib dapat menghambat proses pembelajaran karena secara ekstrim dapat mengecilkan usaha dan kemampuan siswa dalam belajar yang dapat menimbulkan sikap pasif dan mudah menyerah. Sehingga ketika konsepsi jengah muncul pada proses pembelajaran, siswa akan memiliki rasa ingin tahu yang tinggi dan berpengaruh terhadap meningkatnya pemahaman konsep matematika.

Karakteristik yang ketiga yaitu media pembelajaran memuat scaffolding untuk mendukung peningkatan pemahaman konsep matematika siswa. Gambar 6 menunjukan salah satu contoh scaffolding yang ada dalam media yaitu dengan memberikan kata kunci. Selain itu terdapat juga bantuan berupa pertanyaan pancingan, video ilustrasi, dan petunjuk simbolik.

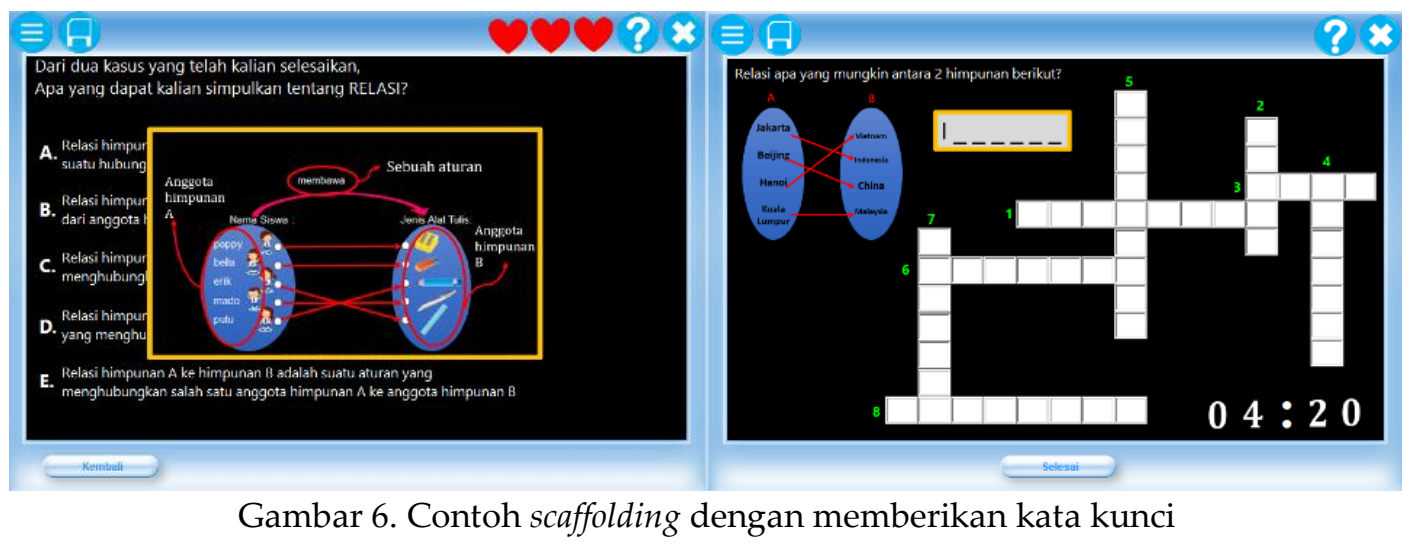

Eksplorasi yang ada dalam media pembelajaran dirancang untuk membantu siswa mengkonstruksi pemahaman siswa terhadap konsep relasi dan fungsi. 
Selain media pembelajaran yang berfungsi sebagai scaffolding, guru juga dapat membantu ketika siswa merasa kebingungan ataupun merasa kurang tepat dalam menjawab pertanyaan-pertanyaan yang diberikan. Tidak menutup kemungkinan, siswa lain dalam proses pembelajaran dapat memberikan bantuan/scaffolding untuk membantu dalam mengkonstruksi konsep relasi dan fungsi (Winer \& Schmid, 2017). Melalui scaffolding yang diperoleh baik itu dari media pembelajaran, guru maupun teman sejawat, pada akhirnya siswa mampu memahami konsep yang sedang dibelajarkan (Ardana, Ariawan \& Divayana, 2018). Pembelajaran dengan scaffolding menyebabkan keterlibatan siswa secara aktif pada proses pembelajaran, melatih siswa untuk menyelesaikan masalah dan juga merasa menikmati proses pembelajaran yang dilaksanakan di kelas (Sudarman \& Linuhung, 2017). Hal tersebut menjadi faktor yang mempengaruhi pemahaman konsep siswa yang belajar dengan pembelajaran scaffolding berbeda secara signifikan dengan peningkatan pemahaman konsep siswa yang belajar dengan pembelajaran konvensional dalam penelitian (Sudarman \& Linuhung, 2017).

Pembelajaran dalam penelitian ini dimulai dengan memotivasi siswa dengan memberikan gambaran tentang pentingnya memahami relasi dan fungsi serta contoh dalam kehidupan sehari-hari. Kemudian pemanfaatan teori Bruner yang diperkuat dengan memanfaatkan budaya lokal dan scaffolding, presentasi dan pengambilan kesimpulan, serta evaluasi (Ardana, Ariawan \& Divayana, 2018). Dengan memanfaatkan teori Bruner pada tahap enaktif, guru mengajak siswa berdiskusi bersama tentang pengertian relasi dan mengajukan beberapa pertanyaan untuk memancing siswa memberikan tanggapan tentang relasi yang mereka ketahui sebelum memulai dengan media pembelajaran. Beberapa pertanyaan yang dapat diajukan ke siswa seperti, apa yang kalian ketahui tentang kata "relasi"?, adakah suatu relasi di sekitar kita sekarang? Guru mengarahkan siswa ke contoh relasi yang muncul di media pembelajaran yaitu relasi "membawa alat tulis". Guru menanyakan beberapa siswa mengenai alat tulis apa saja yang mereka bawa dengan meminta untuk menunjukkannya. Siswa diarahkan untuk memilih kata-kata yang tepat menggambarkan antara dirinya dengan barang yang ditunjukkannya.

Selanjutnya siswa membuka aplikasi media pembelajaran yang sudah ada pada laptop atau komputer masing-masing. Dengan adanya gambar-gambar pada media, siswa memanfaatkan teori Bruner tahap ikonik yaitu siswa mengidentifikasi masalah- masalah pada media pembelajaran tersebut. Melalui kegiatan ini indikator yang dicapai siswa yaitu siswa mampu menentukan suatu relasi/hubungan antara dua objek/aktivitas. Tampilan 
eksplorasi pada media mengenai relasi "membawa alat tulis" yang sebelumnya telah dijelaskan terlihat seperti Gambar 2. Siswa akan melanjutkan ke tahap berikutnya yaitu belajar melalui simbol-simbol yang terdapat pada relasi. Kegiatan ini masuk pada tahap simbolik pada teori Bruner, pada media terlihat seperti Gambar 3.

Pada media pembelajaran sudah terdapat beberapa bantuan untuk membantu siswa memahami konsep materi. Selain pada media, guru juga turut membantu siswa jika belum mampu menangani permasalahan yang dihadapi. Contoh scaffolding pada media terlihat pada Gambar 6. Pemberian bantuan dilakukan dengan mengajukan pertanyaan-pertanyaan yang berkaitan dengan materi prasyarat atau pengajuan pertanyaan yang mampu mengembangkan kemampuan berpikir tingkat tinggi siswa disertai dengan kalimat-kalimat sugesti yang dapat mengembangkan konsepsi jengah siswa. Salah satu tantangan yang ada di media untuk membangkitkan rasa jengah siswa adalah seperti Gambar 5.

Tahap selanjutnya adalah presentasi dan pengambilan kesimpulan. Siswa memaparkan hasil temuan yang didapat dari masalah-masalah yang telah diselesaikan. Siswa yang lain memberikan tanggapan terhadap paparan temannya. Tidak lupa guru juga memberikan tanggapan atau umpan balik. Tahap terakhir yaitu evaluasi, guru memberikan kuis sebagai hasil evaluasi kemampuan siswa setelah mempelajari materi relasi dan fungsi.

Dengan melaksanakan pembelajaran ini, guru tidak kesulitan dalam mengatur waktu untuk melaksanakan tahapan-tahapannya, karena sebagian besar sintak model B2LS ini telah terancang pada media pembelajaran. Mulai dari pendahuluan $( \pm 10$ menit), Pemanfaatan teori Bruner, Konsepsi Jengah dan Scaffolding dengan penggunaan media pembelajaran $( \pm 45$ menit), presentasi dan pengambilan kesimpulan $( \pm 15$ menit) serta evaluasi $( \pm 10$ menit). Setiap pertemuan pada media pembelajaran telah disusun sedemikian rupa untuk 2 jam pelajaran (80 menit).

\section{Simpulan}

Penelitian ini telah berhasil mengembangkan media pembelajaran berbasis model Bruner, Budaya Lokal dan scaffolding yang valid, praktis, dan efektif serta memiliki karakteristik yang membedakannya dengan media pembelajaran yang lain. Penerapan pembelajaran media pembelajaran berbasis model B2LS di dalam kelas didahului dengan guru memberikan apersepsi kemudian memanfaatkan teori Bruner, Budaya Lokal dan scaffolding, presentasi dan komunikasi, serta evaluasi. 


\section{Daftar Pustaka}

Akçakın, V. (2018). Teaching Mathematical Functions Using Geometric Functions Approach and Its Effect on Ninth Grade Students' Motivation. International Journal of Instruction, $11(1), 17-32$.

Ardana, I. M. (2014). Efektivitas B2LS dalam Pembelajaran Matematika. Makalah disajikan dalam Seminar Nasional FMIPA Undiksha IV, Oktober. Singaraja: Undiksha.

Ardana, I. M. (2015). Kepraktisan Model B2LS dalam Pembelajaran Matematika. Makalah disajikan dalam Seminar Nasional Riset Inovatif III, November. Bali: Undiksha Press.

Ardana, I. M. (2016). Meminimalisir Kecemasan Berkomunikasi Siswa dalam Pembelajaran Matematika Melalui Penerapan Model B2LS. Makalah disajikan dalam Prosiding Seminar Nasional MIPA, Agustus. Singaraja: Undiksha Press.

Ardana, I. M., Ariawan, I. P. W., \& Divayana, D. G. H. (2018). Budaya dalam Pembelajaran Matematika. Depok: PT Raja Grafindo Persada.

Denbel, D. G. (2015). Functions in the Secondary School Mathematics Curriculum. Journal of Education and Practice, 6(1), 77-81.

Fonger, N. L., Ellis, A., \& Dogan, M. F. (2016). Students' Conceptions Supporting Their Symbolization and Meaning of Function Rules. Tucson, AZ: The University of Arizona, 8.

Gonulal, T., \& Loewen, S. (2018). Scaffolding Technique. In J. I. Liontas, T. International Association, \& M. DelliCarpini (Eds.), The TESOL Encyclopedia of English Language Teaching (pp. 1-5). John Wiley \& Sons, Inc.

Lestari, D. (2013). Penerapan Teori Bruner Untuk Meningkatkan Hasil Belajar Siswa Pada Pembelajaran Simetri Lipat di Kelas IV SDN 02 Makmur Jaya Kabupaten Mamuju Utara. Jurnal Kreatif Tadulako Online 3(2), 129-141.

Lovita, R. (2017). Keefektifan Penggunaan Media Benda Konkret Terhadap Kemampuan Mengenal Huruf pada Siswa Cerebral Palsy Kelas III di SLB Negeri 1 Bantul. Jurnal Widia Ortodidaktika, 6(3), 241-251.

Matsumoto, K. (2017). A review of Jerome Bruner's educational theory: 19.

McCulloch, A., Lovett, J., \& Edgington, C. (2017). Developing Preservice Teachers' Understanding of Function Using a Vending Machine Metaphor Applet. Indianapolis, IN: Hoosier Association of Mathematics Teacher Educators, 1(8), 1281-1288.

Muhson, A. (2010). Perkembangan Media Pembelajaran Berbasis Teknologi Informasi. Jurnal Pendidikan Akuntansi Indonesia, VIII (2), 1-10.

Novyarti, E., Marzal, J., \& Rohati, R. (2014). Pengembangan Media Pembelajaran Menggunakan Adobe Flash Dan Autoplay Media Studio Dalam Pembelajaran Yang Berbasis Inquiry Pada Materi Garis Dan Sudut Kelas VII SMP. EDUMATICAI Jurnal Pendidikan Matematika, 4(02), 77-84.

Ormond, C. (2016). Scaffolding the Mathematical "Connections": A New Approach to Preparing Teachers for the Teaching of Lower Secondary Algebra. Australian Journal of Teacher Education, 41(6), 122-164.

Purwadi, I. M. A., Sudiarta, I. G. P., \& Suparta, I N. (2019). The Effect of Concrete-PictorialAbstact Strategy toward Students' Mathematical Conceptual Understanding and Mathematical Representation on Fractions. International Journal of Instruction 12(1), 1113-1126.

Razak, A., \& Rumainur. (2018). Efetivitas Penggunaan Multimedia Autoplay Etnik Kalimantan Timur terhadap Hasil Belajar Matematika SD Fastabiqul Khairat Kelas VI di Kota Samarinda. JMIE: Journal of Madrasah Ibtidaiyah Education, 2 (1), 87-96.

Rosmayanti. (2018). Pembelajaran Matematika Dengan Menggunakan Media Gambar di Kelas 1 SDN 017 Seberang Cengar Kecamatan Kuantan Mudik. Jurnal PAJAR 
(Pendidikan Dan Pengajaran) Program Studi Pendidikan Guru Sekolah Dasar FKIP Universitas Riau, 2(3), 419-423.

Sani, M. A. (2017). The Contributions of Jerome Bruner's Constructivist Approach to Education. Indian Journal of Research, 6 (2), 79-96.

Serdyukov, P. (2017). Innovation in education: What works, what doesn't, and what to do about it? Journal of Research in Innovative Teaching $\mathcal{E}$ Learning, 10(1), 4-33.

Sudarman, S. W., \& Linuhung, N. (2017). Pengaruh Pembelajaran Scaffolding Terhadap Pemahaman Konsep Integral Mahasiswa. Jurnal Pedidikan Matematika FKIP Univ. Muhamadiyah Metro, 6(1), 33-39.

Sugiyono. (2017). Metode Penelitian Kuantitatif Kualitatif dan RED. Bandung: Alfabeta.

Takaya, K. (2008). Jerome Bruner's Theory of Education: From Early Bruner to Later Bruner. Interchange, 39(1), 1-19.

Wandani, N. M., \& Syaiful Hamzah Nasution. (2017). Pengembangan Multimedia Interaktif Dengan Autoplay Media Studio Pada Materi Kedudukan Relatif Dua Lingkaran. 1 (2). $2549-8584$.

Winer, L. R., \& Schmid, R. F. (2017). Using Brunerian Learning Theory with Educational Simulations to Teach Concepts. Canadian Journal of Learning and Technology / La Revue Canadienne de l'apprentissage et de La Technologie, 15(3), 153-165. 